\title{
Leafy spurge and grass response to picloram and intensive grazing
}

\author{
JOHN R. LACEY AND ROGER L. SHELEY
}

\begin{abstract}
Authors are former extension range management specialist, Animal and Range Sciences, and assistant professor, Plant, Soil and Environmental Sciences, respectively, Montana State University, Bozeman, Mont. 59717. Research was partially funded by Montana Noxious Weed Trust Fund, Montana Wool Growers, Dow Elanco, and Crazy Mountain Ranch.
\end{abstract}

\begin{abstract}
More information about the effects of combining intensive livestock grazing of noxious weeds and associated desirable plants with other control measures is needed to develop effective rangeland weed management strategies. We studied the response of leafy spurge (Euphorbia esula L.) and Kentucky bluegrass (Poa pratensis $\mathbf{L}$.) to intensive short-duration grazing by either sheep or cattle, in combination with picloram (4-amino-3,5,6trichloropicolinic acid) for 5 years. In the first year, 2 pastures (16 and 24-ha) were split into 3 blocks and picloram was applied to one-half of each block at a rate of $0.9 \mathrm{~kg} \mathrm{ha}^{-1}$. Exclosures were established to include both treated and untreated portions in each block. The smaller and larger pastures were grazed by sheep and cattle, respectively. There were 1 or 2 grazing periods per year, varying from 1- to 2-days in length. Leafy spurge stem densities were counted annually, and grass cover and plant biomass were also examined. Data from each pasture (cattle or sheep) were analyzed separately using analyses of variance. Leafy spurge was selectively grazed by sheep, and stem densities were reduced by sheep grazing $(\mathbf{P}<0.01)$. Cattle did not utilize leafy spurge and stem densities were not affected. Picloram reduced leafy spurge stem densities throughout the study in both the sheep $(\mathbf{P}<0.001)$ and cattle $(\mathbf{P}<0.001)$ pastures. Picloram also reduced leafy spurge biomass in the sheep pasture $(P<0.05)$, which allowed an increase in Kentucky bluegrass biomass. Grazing $X$ picloram interactions affecting either leafy spurge stem densities or leafy spurge biomass were not detected. An integrated leafy spurge management system may require a longer time frame, additional control measures, and (or) more intensive grazing management.
\end{abstract}

Key Words: Euphorbia esula, Kentucky bluegrass, rangeland, biological control, noxious weeds

Leafy spurge (Euphorbia esula L.), a Eurasian invader currently infests over 600,000 ha of grazing land in North and South Dakota, Montana, and Wyoming. Infested areas continue to expand rapidly (Leistritz et al. 1992), threatening many native plant communities in the western U.S. The plant is long-lived, has a wide ecological amplitude, reproduces vegetatively and by

Published as Montana Agr. Exp. Tech. Paper No. J-3053.

Manuscript accepted 8 Sep 96. seed, has few natural enemies in North America, and contains compounds which cause some livestock to develop an aversive response to it (Selleck et al. 1962, Bowes and Thomas 1978, Lym and Kirby 1987, Kronberg et al. 1993). Most animals have preferences for certain forages. Under continuous grazing the preferred forages are eventually reduced or eliminated, which decreases their role as competitors in the plant community (Crawley 1983, Louda et al. 1990). Theoretically, cattle grazing can reduce grasses and increase the susceptibility of the plant community to invasion by less-preferred weedy species. Intensive grazing by animals preferring forbs, such as sheep and goats, can shift the plant community toward more desired grasses.

Previous research has shown that cattle avoid leafy spurge infested sites (Lym and Kirby 1987, Hein and Miller 1992). In contrast, leafy spurge is a suitable forage for sheep (Landgraf et al. 1984, Bartz et al. 1985, Walker et al. 1992), and in some situations can be controlled by them (Johnston and Peake 1960, Bowes and Thomas 1978, and Lacey et al. 1984)

Long-term chemical control of leafy spurge is extremely difficult to achieve. Picloram (4-amino-3,5,6-trichloropicolinic acid) is the most effective chemical for reducing leafy spurge density, but only provides short-term control (Lym and Messersmith 1987). A combination of chemical, cultural, or biological control may be necessary to provide sustainable control (Alley et al. 1984, Dershield et al. 1985, Sedivec and Maine 1993).

Although much research has focused on controlling leafy spurge, the effects of livestock grazing on leafy spurge-dominated plant communities are poorly understood; especially the effects of short-duration livestock grazing in combination with herbicide application. We evaluated the effects of short-duration cattle or sheep grazing, in combination with picloram on leafy spurge and Kentucky bluegrass (Poa pratensis L.). Information should be useful in developing integrated management strategies for managing leafy spurge on rangeland.

\section{Materials and Methods}

\section{Study Site}

This study was conducted at the Crazy Mountain Ranch $\left(45^{\circ}\right.$ $45^{\prime} \mathrm{N}, 110^{\circ} 23^{\prime} \mathrm{W}$, elev. $2,100 \mathrm{~m}$ ) approximately $6 \mathrm{~km}$ east of Clyde Park, Montana. Mean annual precipitation is about $50 \mathrm{~cm}$, with 55\% received during the growing season (May-September). 
About $2,680 \mathrm{~kg} \mathrm{ha}^{-1}$ of total herbage is produced annually on the silty range sites (well drained soils that are moderately fine in texture). Herbage is comprised of Kentucky bluegrass (75\%), leafy spurge (20\%), and other plants (5\%). The proximity of old buildings indicated that the area was homesteaded and farmed in the early 1900 's.

\section{Methods}

Two pastures (16 and 24-ha) were fenced in 1990. Each pasture was divided into 3 equal blocks, one-half of which was randomly selected for herbicide treatment. A single application of picloram was applied at a rate of $0.9 \mathrm{~kg} \mathrm{ha}^{-1}$ in June 1990 . Three permanent exclosures $(8 \times 30 \mathrm{~m})$ were constructed in each of the pastures. Each exclosure straddled the boundary line between the picloram-treated and nonpicloram-treated strip of each block. For each of these strips, 2 permanent transects $(30-\mathrm{m})$ were established inside, and 2 parallel transects were established outside of its exclosure. A total of 24 transects were established in each pasture. Five permanent plots $\left(0.5 \mathrm{~m}^{2}\right)$ were systematically located along each transect. Transect and plot locations were marked with iron stakes and 15-cm nails, respectively. Three or 2 utilization cages $\left(1 \mathrm{~m}^{2}\right)$ were located in each picloram-treated and each nonpicloram-treated strip in the 16-ha and the 24-ha pasture, respectively. Thus, the pastures grazed by sheep and cattle contained 18 and 12 utilization cages, respectively.

The 16-ha pasture was grazed annually by about 1,100 targhee ewes with lambs. The grazing period usually lasted 2 days, and occurred in early July when leafy spurge was flowering. Twice during the 5-year period, the sheep regrazed the pasture for 1 day in early September. The 24-ha pasture was grazed annually by cattle. During the first 2 years of the study, 500 cows with calves grazed the pasture for 2 days in early July. About 525 yearling heifers grazed the pasture in the remaining years. Except for the short grazing periods, livestock were excluded from the pastures for the remainder of the year.

Leafy spurge stems were counted annually in the plots along each transect. Counts in the initial and final years were made in September. Density data in other years were collected in June.

Kentucky bluegrass foliar cover, the percent of the plot occupied, was estimated within each of the $0.5 \mathrm{~m}^{2}$ plots located along the transects at the beginning of the study. Cover was classified into 6 classes: $1=0-10 \%, 2=11-25 \%, 3=26-50 \%, 4=$ $51-75 \%, 5=76-90 \%$, and $6=91-100 \%$.

Leafy spurge and Kentucky bluegrass utilization was estimated immediately following grazing, from 1990 through 1993, by clipping plots inside and outside of the utilization cages. In 1994, above-ground biomass of leafy spurge and Kentucky bluegrass was clipped to ground level inside the exclosures and utilization cages. The former represented yield after 5 years of protection, while the latter represented yield after 1 year of protection from livestock grazing. After collection, all herbage samples were separated by species, oven-dried for 48 hours at $65^{\circ} \mathrm{C}$ and weighed.

\section{Analysis}

Data from cattle and sheep pastures were analyzed separately. Leafy spurge stem densities (1991, 1992, 1993, and 1994), were analyzed using analyses of variance (SAS 1990). Main effects were year $(n=4)$, grazing (grazed vs. not grazed), and picloram (picloram vs. no picloram). Grazing by herbicide interactions were included. Analysis of stem density and cover data collected in 1990 indicated that blocks were similar. Separate analyses of variance were used to determine effects of treatments on Kentucky bluegrass cover and bunchgrass (Stipa spp; Danthonia ssp.) density within year (1990 and 1994), and biomass (leafy spurge and grass) in 1994.

\section{Results}

\section{Sheep Grazing}

Sheep utilized from $65-86 \%$ of the leafy spurge annually (data not shown). Leafy spurge stem densities were reduced by sheep grazing $(\mathrm{P}<0.01)$ and by the application of picloram $(\mathrm{P}<0.001)$. Regardless of treatment, stem densities increased $(\mathrm{P}<0.001)$ during the study $(1991<(1992=1994)<(1994=1993))$ (Fig. 1). Significant $(P<0.10)$ grazing $\times$ picloram interactions on stem densities were not detected.

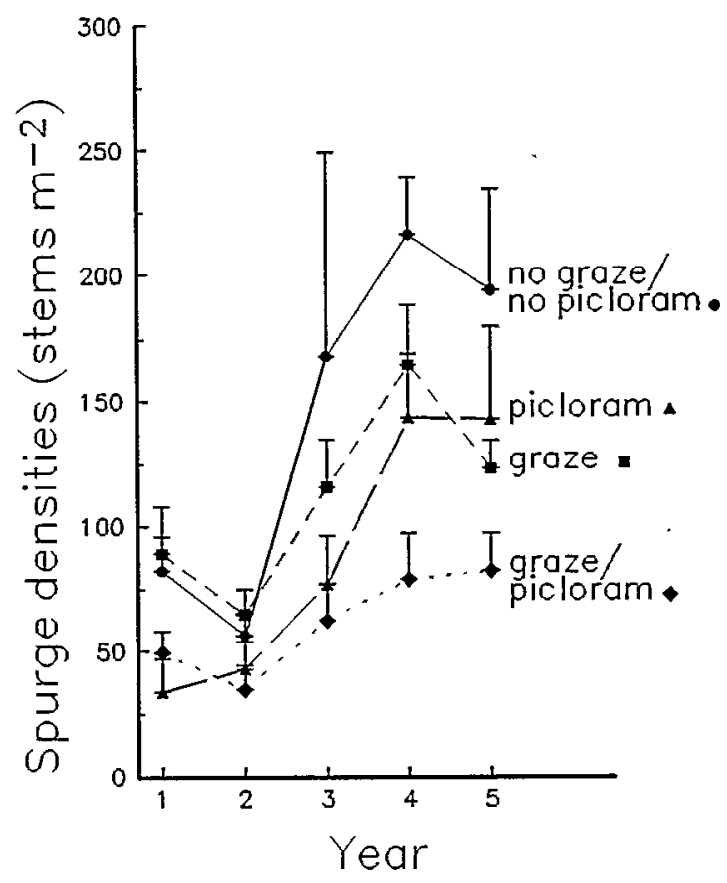

Fig. 1. Densities (means and standard deviations) of leafy spurge stems by year in the sheep pasture at Clyde Park.

Neither leafy spurge (mean $=4.75 \mathrm{~kg} \mathrm{ha}^{-1} ; \mathrm{P}=0.18$ ) nor Kentucky bluegrass (mean $=20.85 \mathrm{~kg} \mathrm{ha}^{-1} ; \mathrm{P}=0.48$ ) biomasses were affected by sheep grazing. Picloram reduced leafy spurge $(\mathrm{P}<0.10)$ from 5.7 to $3.7 \mathrm{~kg} \mathrm{ha}^{-1}$ and increased Kentucky bluegrass $(\mathrm{P}=<0.05)$ from 17.5 to $24.3 \mathrm{~kg} \mathrm{ha}^{-1}$. Significant $(\mathrm{P}=<0.10)$ grazing $\times$ picloram interactions on leafy spurge biomass were not detected.

Kentucky bluegrass cover was similar among treatments in 1990. Four years later, coyer was not affected by either sheep grazing (mean $=2.8 \% ; \mathrm{P}=0.18$ ) or picloram (mean $=2.85 ; \mathrm{P}=$ $0.91)$. Bunchgrass density was initially higher $(P<0.10)$ in the picloram treated strips; but by 1994, no differences were detected (mean $=0.48$ plants $\mathrm{m}^{-2} ; \mathrm{P}=0.26$ ).

\section{Cattle Grazing}

Leafy spurge stem densities increased $(\mathrm{P}<0.0001)$ during the study $(1991<(1992=1994)<1993)$ (Fig. 2). Stem densities were not affected $(\mathrm{P}=0.66)$ by cattle which did not utilize leafy spurge. Stem densities were reduced $(\mathrm{P}<0.001)$ by picloram. 


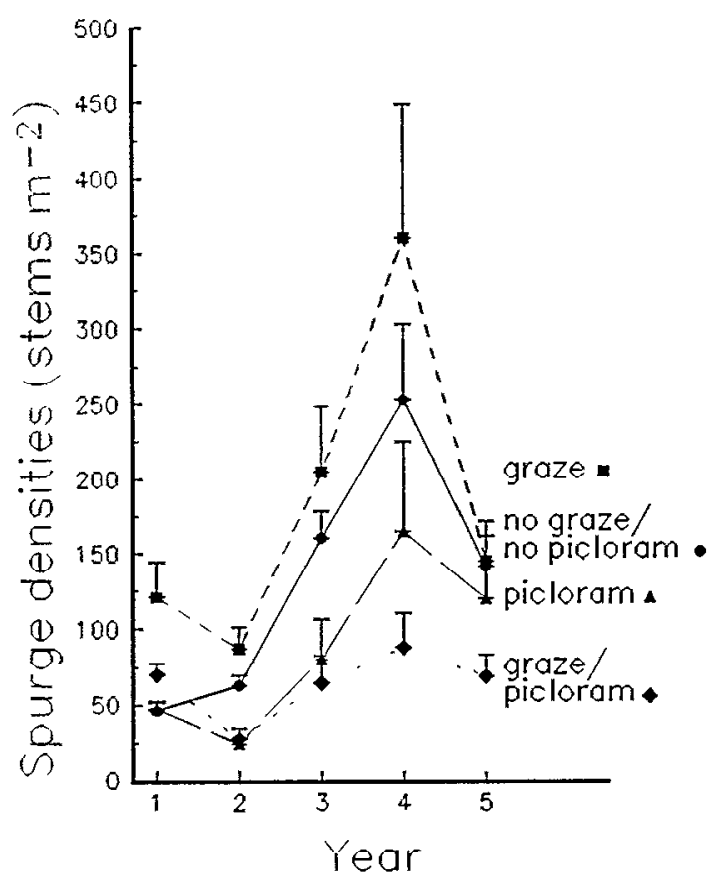

Fig. 2. Densities (means and standard deviations) of leafy spurge stems by year in the cattle pasture at Clyde Park.

Above-ground biomass of leafy spurge was not affected by grazing (mean $=6.65 \mathrm{~kg} \mathrm{ha}^{-1} ; \mathrm{P}=0.54$ ) or by picloram (mean $=$ $6.75 \mathrm{~kg} \mathrm{ha}^{-1} ; \mathrm{P}=0.91$ ) but Kentucky bluegrass was influenced by a significant grazing $\times$ picloram interaction (Fig. 3 ). The biomass of Kentucky bluegrass increased when picloram treatments were combined with cattle grazing but not by picloram treatment alone.

Kentucky bluegrass cover was similar among treatments in 1990. Four years later, mean cover class increased from 2.9 to 3.3 with either cattle grazing $(\mathrm{P}<0.05)$ or with picloram $(\mathrm{P}<0.01)$. Bunchgrass densities $\left(0.48\right.$ plants $\left.\mathrm{m}^{-2}\right)$ were similar among treatments throughout the study.

\section{Discussion}

Lassiz faire policies are not recommended for controlling leafy spurge infestations. Without sheep grazing or picloram, leafy spurge stems doubled from 1990 to 1994 (Fig. 1), and there was no evidence of native plant community restoration. Leafy spurge increases were reduced with sheep grazing and picloram. In comparison to no grazing, the benefits of sheep grazing became most noticeable between the 2 nd and 3 rd grazing season after picloram application (Fig. 1).

Results from our study are not in complete agreement with other studies. While sheep grazing reduced leafy spurge stem densities in the present study, results were less dramatic than those reported by Johnston and Peake (1960) and Bowes and Thomas (1978). However, the former study was conducted in a crested wheatgrass (Agropyron cristatum L.)-leafy spurge pasture, and the latter employed heavy season-long grazing.

We did not observe the increased growth of associated species that were reported by Montana ranchers (Lacey et al. 1984). These differences may be explained by differences in grazing management. Most leafy spurge-infested pastures are apparently grazed season-long. In contrast, our study utilized a short-duration grazing system. Although high animal density for short grazing periods normally reduces animal selectivity, our sheep selected leafy spurge in favor of Kentucky bluegrass. After 2 days of grazing, utilization of spurge varied from 65 to $86 \%$, while utilization of grass varied from 26 to $45 \%$ annually. In comparison to plants protected from sheep grazing, the sheep-grazed leafy spurge stems tended to be shorter and produced fewer flowers. Although vigor was reduced by grazing, it is possible that leafy spurge recovered during the long non-grazing period. The effect of incorporating frequent grazing periods into our short-duration grazing strategy are unknown.

Our results indicate that a single application of picloram may partially control leafy spurge for 4 to 5 years. Because annual applications of picloram plus 2,4-D (2,4 dichorophenoxy acetic acid) at 0.28 and $1.1 \mathrm{~kg} \mathrm{ha}^{-1}$, respectively, are normally required to achieve about $90 \%$ leafy spurge control (Lym and Messersmith 1987), control in our study may have been enhanced by the higher picloram rate $\left(0.9 \mathrm{~kg} \mathrm{ha}^{-1}\right)$ and by the short duration grazing program.

A synergistic effect of picloram and sheep grazing may exist. From 1990 through 1993, there were fewer leafy spurge stems in the picloram-treated plots than in the sheep-grazed plots (Fig. 1). However in 1994, there were fewer leafy spurge stems in the sheep-grazing treatment than in the picloram treatment. In contrast, we were able to obtain the best results with the combination of sheep grazing and picloram. Results are expected to vary with the timing, frequency, or severity of defoliation.

Sheep selectively grazed leafy spurge, regardless of stem density, in our study. In contrast, sheep avoided high densities of flowering stems in Idaho (Walker et al. 1994). These differences may be related to inherent variability within leafy spurge.

Stem densities fluctuated annually at our study site. Much of the variation is attributed to precipitation (Table 1). In contrast to 1994, favorable precipitation enhanced seedling establishment in 1993. Selleck et al. (1962) attributed fluctuating stem densities in Saskatchewan to precipitation, competition and other environmental factors. The inclusion of seedlings in density measurements increased the variability of stem densities in our data.

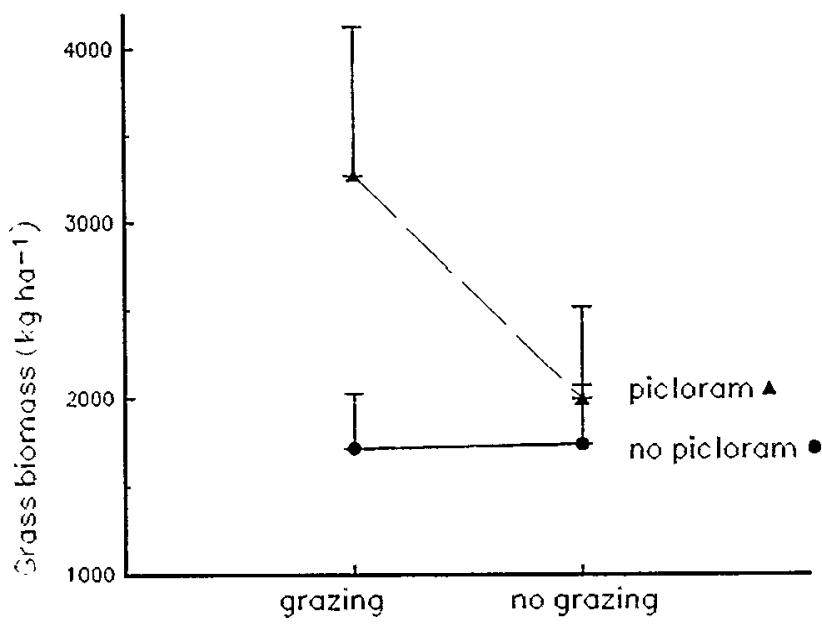

Fig. 3. Interaction of grazing $\times$ picloram on grass biomass in the cattle pasture at Clyde Park. 
Table 1. Monthly precipitation (cm) and deviation from 30 year normal for Wilsall, Mont., the most representative climatological station.

\begin{tabular}{|c|c|c|c|c|c|c|c|c|c|c|}
\hline \multirow[t]{2}{*}{ Month } & \multicolumn{2}{|c|}{1990} & \multicolumn{2}{|c|}{1991} & \multicolumn{2}{|c|}{1992} & \multicolumn{2}{|c|}{1993} & \multicolumn{2}{|c|}{1994} \\
\hline & ppt & $\mathrm{dev}$ & ppt & dev & ppt & dev & $\mathrm{ppt}$ & dev & $\mathrm{ppt}$ & dev \\
\hline & -- & $-\cdots$ & -- & --- & --- & -- & --- & --- & -- & -- \\
\hline April & 6.68 & 2.11 & 8.48 & 3.91 & 10.69 & 6.12 & 10.87 & 6.30 & 5.87 & 1.30 \\
\hline June & 3.71 & -4.44 & 5.69 & -2.46 & 16.92 & 8.77 & 11.43 & 3.28 & 8.10 & -0.05 \\
\hline July & 3.20 & -1.06 & 0.58 & -3.68 & 7.21 & 2.95 & 18.26 & 14.00 & 5.99 & 1.73 \\
\hline August & 4.22 & -0.40 & 3.63 & -0.99 & 3.33 & -1.29 & 8.94 & 4.32 & 0.84 & -3.78 \\
\hline October & 2.29 & -1.52 & 1.93 & -1.88 & 6.30 & 2.49 & 2.13 & -1.68 & 6.83 & 3.02 \\
\hline Total & 43.36 & -8.99 & 51.03 & -1.32 & 66.32 & 13.97 & 79.53 & 27.18 & 42.82 & -9.27 \\
\hline
\end{tabular}

Kentucky bluegrass biomass generally increased with picloram treatments as competition from leafy spurge was reduced. However, production eventually declined in the cattle pasture, where selective grazing of grasses gave leafy spurge a competitive advantage. Although grass biomass in the cattle pasture declined as leafy spurge biomass increased, Kentucky bluegrass cover remained higher with grazing. Grazing decreased the excessive accumulation of Kentucky bluegrass litter which suppresses production.

Our study tried to integrate intensive livestock grazing with picloram to control leafy spurge. Although leafy spurge densities increased during the 5-year period, increases were reduced with sheep grazing and picloram treatments. An integrated system for managing leafy spurge may require a longer time frame, additional control measures, and (or) a more intensive grazing management program.

\section{Literature Cited}

Alley, H.P., N.E. Humberg, J.K. Fornstrou, and M. Ferrell. 1984. Leafy spurge (Euphorbia esula) control with repetitive herbicide treatments. Res. Weed Sci., Wyo. Agric. Exp. Sta. Res. J. 192:90-93.

Bartz, S., B. Landgraf, P. Fay, and K. Havstad. 1985. Leafy spurge as a forage component for ewes and lambs. SID Research Digest, Winter 1985. p. 39-42.

Bowes, G.G. and A.G. Thomas. 1978. Longevity of leafy spurge seeds in the soil following various control programs. J. Range Manage. 31:137-140.

Crawley, J.J. 1983. Herbivory: The Dynamics of Animal-Plant Interactions. Univ. of Califomia Press, Berkeley, Calif.

Dersheid, L.A., LJ. Wrage, and W.E. Arnold. 1985. Cultural control of leafy spurge. p. 57-64. In: A.K. Watson ed. Leafy Spurge Mongr. 3. Weed Sci. Soc. Amer., Champaign, Ill. 61820.

Hein, D.G. and S.D. Miller. 1992. Influence of leafy spurge on forage utilization by cattle. J. Range Manage. 45:405-407.

Johnston, A. and R.W. Peake. 1960. Effect of selective grazing by sheep on the control of leafy spurge (Euphorbia esula L.). J. Range Manage. 13:192-195.

Kronberg, S.L., R.B. Muntifering, E.L. Ayers, and C.B. Marlow. 1993. Cattle avoidance of leafy spurge: A case of condition aversion. J. Range Manage. 46:364-366.

Lacey, C.A., R.W. Kott, and P.K. Fay. 1984. Ranchers control leafy spurge. Rangelands 6:202-204.

Landgraf, B.K., P.K. Fay, and K.M. Havstad. 1984. Utilization of leafy spurge (Euphorbia esula) by sheep. Weed Sci. 32:348-352.
Leistritz, F.L., F. Thompson, and J.A. Leitch. 1992. Economic impact of leafy spuge (Euphorbia estla) in North Dakota. Weed Sci. 40:275280.

Louda, S.M., K.H. Keeler, and R.D. Holt. 1990. Herbivore influences on plant performance and competitive interactions. pp. 413-444. In: Perspectives on Plant Competition. J.B. Grace and D. Tilman (Eds). Academic Press, Inc., San Diego, Calif.

Lym, R.G. and D.R. Kirby. 1987. Cattle foraging behavior in leafy spurge (Euphorbia esula)-infested rangeland. Weed Technol. 1:314-318.

Lym, R.G. and C.G. Messersmith. 1987. Leafy spurge control and herbicide residue from annual picloram and 2, 4-D application. J. Range Manage. 40:194-198.

SAS Institute, Inc. 1990. SAS/STAT User's Guide, Version 6, Fourth Edition, Vol. 2, SAS Inst., Cary, N.C. p. 886.

Sedivec, K.K. and R.P. Maine. 1993. Angora goat grazing as a biological control for leafy spurge: a three year summary. Proceed. Leafy Spurge Symposium, GPC-14, Colorado State Univ., Fort Collins, Colo.

Selleck, G.W., R.T. Coupland, and C. Frankton. 1962. Leafy spurge in Saskatchewan. Ecol. Mono. 32:1-29.

Walker, J.W., K.G. Hemenway, P.G. Hatfield, and H.A. Glimp. 1992. Training lambs to be weed eaters: studies with leafy spurge. J. Range Manage. 45:245-249.

Walker, J.W., S.L. Kronberg, S.L. Al-Rowaily, and N.E. West. 1994. Comparison of sheep and goat preferences for leafy spurge. J. Range Manage. 47:429-434. 